\title{
Effect of Fungicide Application on the Management of Avocado Branch Canker (Formerly Dothiorella Canker) in California
}

\author{
M. Twizeyimana, V. McDonald, J. S. Mayorquin, D. H. Wang, and F. Na, Department of Plant Pathology and Microbiology, \\ University of California, Riverside; D. S. Akgül, Viticulture Research Station, Turkish Department of Agriculture, 45040, Horozkoy, \\ Manisa, Turkey; and A. Eskalen, Department of Plant Pathology and Microbiology, University of California, Riverside 92521
}

\begin{abstract}
Twizeyimana, M., McDonald, V., Mayorquin, J. S., Wang, D. H., Na, F., Akgül, D. S., and Eskalen, A. 2013. Effect of fungicide application on the management of avocado branch canker (formerly Dothiorella canker) in California. Plant Dis. 97:897-902.

Members of the Botryosphaeriaceae family have been associated with branch cankers of avocado trees (Persea americana) in California. Canker infections are initiated by spores entering the host plant through fresh wounds such as pruning wounds. With high-density planting becoming more common in the California avocado industry, more intensive pruning may increase the occurrence of branch canker. The objective of this study was to evaluate the preventive ability of some commercial fungicides belonging to different chemical families against fungal pathogens associated with avocado branch canker. Initially, 12 fungicides were tested in vitro for their effect on the inhibition of mycelial growth of three isolates of Dothiorella iberica and isolates (five per species) of Neofusicoccum australe, N. luteum, $N$. parvum, and Phomopsis sp. Subsequently, azoxystrobin, fludioxonil, metconazole, and pyraclostrobin, selected because of their low effec-

tive concentrations that reduce $50 \%$ of mycelial growth ( $\mathrm{EC}_{50}$ values), and myclobutanil, selected for its high $\mathrm{EC}_{50}$ value, were tested in two field experiments. Azoxystrobin and fludioxonil were used in a premix with propiconazole and cyprodinil, respectively, in field trials. Significant differences $(P<0.05)$ were observed among fungicides in field trials. Azoxystrobin + propiconazole had the highest percent inhibition at 52 and $62 \%$ (internal lesion length) in trial 1 and trial 2, respectively, although this level of inhibition was not significantly different from that of metconazole. A significant correlation $(r=0.51, P<0.05)$ was observed between internal lesion length data in the field experiment and $\mathrm{EC}_{50}$ data from in vitro fungicide screening. Application of azoxystrobin + propiconazole and metconazole can play a key role in protecting Californian avocado against fungi causing avocado branch canker.
\end{abstract}

Avocado (Persea americana Mill.) is a major fruit crop in the tropics and subtropics. Over 3.4 million metric tons of fruit were produced in 2010 worldwide, with $29 \%$ of the world production in Mexico (12). In the United States, California is the leading producer of avocado fruit, with approximately $90 \%$ of the U.S. production $(3,11)$, followed by Florida and Hawaii (11). During the 2010-2011 growing season, the avocado industry in California accounted for 151,250 metric tons valued approximately at $\$ 460.2$ million (3).

Members of the Botryosphaeriaceae family were the most abundant fungi isolated from avocado branch cankers in California (23). The Botryosphaeriaceae were found alone and in combination with Phomopsis spp. and other fungi belonging to the genera $\mathrm{Bi}$ onectria, Colletotrichum, Schizophyllum, Fusarium, Eutypella, and Phaeoacremonium (23). Diseases caused by species of Botryosphaeriaceae have been reported in California from almond (8), avocado (16), grapevine (37), pistachio (27), and walnut (28), as well as from native chaparral where Botryosphaeria branch dieback has been linked to forest fires (2).

Avocado branch canker has long been known as Dothiorella canker because the pathogen most often isolated was known as Dothiorella gregaria Sacc. (teleomorph Botryosphaeria ribis) (15). Taxonomic revisions have since reclassified this fungus as Fusicoccum aesculi Corda (teleomorph Botryosphaeria dothidea) (31). B. dothidea was the only reported Botryosphaeriaceae species causing Dothiorella branch canker on avocado in California until the report of at least three other Botryosphaeriaceae spp.: Neofusicoccum australe, N. luteum, and N. parvum (23).

Corresponding author: A. Eskalen, E-mail: akif.eskalen@ucr.edu

Accepted for publication 14 January 2013.

http://dx.doi.org/10.1094/PDIS-06-12-0518-RE

(C) 2013 The American Phytopathological Society
Symptoms of avocado branch canker can occur on twigs, branches, or trunks. Canker infections are initiated by spores entering the host plants through fresh wounds such as pruning wounds, mechanical injuries, or injuries resulting from sunburn or frost damage $(24,26)$. Ascospores are produced during winter and spring, while conidia are produced year-round. Both types of spores are infective and can be found in epiphytic fruiting bodies on the surface of asymptomatic tissue of colonized bark and twig (26). Cankers on avocado may exude brownish red or reddish sap that dries to form a whitish-beige powder $(17,24)$. The bark and xylem under the canker is killed and turns red-brown to brown. In older cankers, the dead bark can be easily removed, and if the xylem is colonized, leaves quickly turn brown but remain attached. This may lead to the collapse of branches or entire trees. Canker infections become severe following stress caused by drought, flooding, insect attack, nutrient deficiencies, or any other factor that weakens the tree (26).

High-density planting is becoming more common in California avocado groves, and this necessitates more frequent pruning to manage tree growth. Botryosphaeria spp. are wound-invading pathogens, and more frequent pruning increases the number of wounds available for infection. A spore-trapping study (9) showed that viable Botryosphaeria spores are trapped throughout the year within California avocado groves, with peaks coinciding with rain events. This is consistent with findings from other woody hosts, such as grapevine, which are susceptible to Botryosphaeria spp. (10).

Although there are no reports on yield losses due to avocado branch canker in California, this disease has the potential to infect many avocado trees, resulting in considerable yield reductions. Currently, there are no effective control strategies for the management of avocado branch canker; however, the chemical treatment of open wounds on the tree would be the primary means of protecting avocado trees from Botryosphaeria spp. infection. The objective of this study was to evaluate the preventative ability of some commercial fungicides against fungi associated with avocado branch canker. 


\section{Materials and Methods}

Field location and plant material. The study was conducted in 2011 at the University of California South Coast Research and Extension Center (SCREC) in Irvine, CA $\left(33^{\circ} 44^{\prime} \mathrm{N}, 117^{\circ} 49^{\prime} \mathrm{W}\right)$. Two trials were established in early March and late April. Each trial lasted approximately 6 months. Plantations of 'Hass' avocado trees with 'Duke 7' rootstock were planted in 1990 at a spacing of $6.1 \times 6.1 \mathrm{~m}$. There were approximately 109 trees per acre. The field was irrigated as needed, and standard fertilization practices for California avocado plantations were followed (14).

Fungal pathogens. Isolates of four fungi belonging to the family Botryosphaeriaceae were used in this study: Dothiorella iberica A.J.L. Phillips, Luque \& Alves; Neofusicoccum australe (Slippers, Crous \& M.J. Wingfield) Crous, Slippers \& A.J.L. Phillips; Neofusicoccum luteum (Pennycook \& Samuels) Crous, Slippers \& A.J.L. Phillips; and Neofusicoccum parvum (Pennycook \& Samuels) Crous, Slippers \& A.J.L. Phillips. Isolates of Phomopsis sp., a species that belongs to the family Diaporthaceae and is often isolated from avocado branches' cankers, was also included. There were five isolates for each species except for D. iberica, for which there were three isolates (Table 1). All isolates were established from samples with canker symptoms collected during the field survey conducted between September 2008 and March 2009 from Riverside, San Diego, San Luis Obispo, Santa Barbara, and Ventura counties in California (23).

In vitro fungicide screening. Twelve fungicides belonging to different chemical families (Table 2) were tested in vitro to determine their effective concentrations that reduce $50 \%$ of mycelial growth ( $\mathrm{EC}_{50}$ values) using the spiral gradient dilution (SGD) method (13). Five isolates were tested for $N$. australe, N. luteum, $N$. parvum, and Phomopsis sp., whereas only three isolates of $D$. iberica were tested. Briefly, mycelial inoculum for the SGD plates was grown on hydrophilic cellophane strips (du Pont de Nemours, Wilmington, DE). Eight to 10 cellophane strips were placed on the surface of PDA in 10-cm petri dishes, $10 \mu \mathrm{l}$ of a mycelial suspension $\left(10^{6}\right.$ mycelial tips $\left./ \mathrm{ml}\right)$ was applied evenly onto each cellophane strip, and strips were incubated at $25^{\circ} \mathrm{C}$ for $24 \mathrm{~h}$. Fungicide stock concentrations of 60 to $3,000 \mu \mathrm{g} / \mathrm{ml}$ (Table 3) were spirally applied to $15-\mathrm{cm}$ petri dishes with potato dextrose agar (PDA) using a spiral plater (Spiral System Model D, Spiral Biotech). Plates were incubated for 2 to $4 \mathrm{~h}$ to allow fungicides to diffuse into the medium and form a concentration gradient along the radius of the plate. The mycelium-covered strips, described above, were placed radially along this gradient. The experimental design was a split plot in a randomized complete block design with two replica-

Table 1. Fungal pathogens used in the in vitro fungicide screening and in the field trials

\begin{tabular}{|c|c|c|c|c|}
\hline Species & Isolate $^{a}$ & Host & Origin $^{b}$ & Collected \\
\hline Dothiorella iberica & UCR452* & Persea americana & Ventura & November 2008 \\
\hline D. iberica & UCR1527 & Quercus agrifolia & Orange & January 2011 \\
\hline D. iberica & UCR1711 & Q. agrifolia & Irvine & August 2011 \\
\hline Neofusicoccum australe & UCR160 & P. americana & Riverside & September 2008 \\
\hline N. australe & UCR508 & P. americana & Ventura & November 2008 \\
\hline N. australe & UCR509* & P. americana & Ventura & November 2008 \\
\hline N. australe & UCR515 & P. americana & San Bernardino & November 2008 \\
\hline N. australe & UCR739 & P. americana & San Luis Obispo & March 2009 \\
\hline Neofusicoccum luteum & UCR516* & P. americana & Ventura & November 2008 \\
\hline N. luteum & UCR524 & P. americana & Santa Barbara & November 2008 \\
\hline N. luteum & UCR654 & P. americana & Riverside & September 2008 \\
\hline N. luteum & UCR1211 & P. americana & San Diego & August 2010 \\
\hline N. luteum & UCR1368 & P. americana & San Diego & August 2010 \\
\hline Neofusicoccum parvum & UCR295* & P. americana & San Diego & October 2008 \\
\hline N. parvum & UCR531 & P. americana & Ventura & November 2008 \\
\hline N. parvum & UCR735 & P. americana & San Luis Obispo & March 2009 \\
\hline N. parvum & UCR736 & P. americana & San Luis Obispo & March 2009 \\
\hline N. parvum & UCR737 & P. americana & San Luis Obispo & March 2009 \\
\hline Phomopsis sp. & UCR556* & P. americana & Ventura & November 2008 \\
\hline Phomopsis sp. & UCR609 & P. americana & Mexico & December 2008 \\
\hline Phomopsis sp. & UCR772 & P. americana & San Luis Obispo & March 2009 \\
\hline Phomopsis sp. & UCR781 & P. americana & San Luis Obispo & March 2009 \\
\hline Phomopsis sp. & UCR1395 & P. americana & San Diego & August 2010 \\
\hline
\end{tabular}

a Three isolates for D. iberica and five isolates for each species: $N$. australe, $N$. luteum, $N$. parvum, and Phomopsis sp., were tested in the in vitro fungicide screening, whereas only five isolates (with asterisk) (one isolate per species) were tested in the field. Acronym UCR (in isolate name): University of California, Riverside.

b Names are counties in the state of California except for isolate UCR609 (Phomopsis sp.), which was collected from Mexico.

Table 2. Fungicides tested in the in vitro screening for their ability to control fungi associated with avocado branch canker

\begin{tabular}{lllll}
\hline Active ingredient $^{\mathbf{a}}$ & Commercial name & Formulation $^{\mathbf{b}}$ & Chemical family & Manufacturer \\
\hline Aluminum tris (70) & Aliette & WDG & Organometallic & Bayer Crop Science \\
Azoxystrobin (22.9) & Abound & SC & Strobilurins & Syngenta \\
Cyprodinil (75.0) & Vangard & WG & Pyrimidines & Syngenta \\
Fludioxonil (20.4) & Scholar & SC & Phenylpyrroles & Syngenta \\
Fluopyram (21.4) & Luna Sensation 500 & SC & Benzamide-pyridines & Bayer Crop Science \\
Metconazole (50) & Quash 50 & WDG & Triazoles & Valent \\
Myclobutanil (40) & Rally 40 & WSP & Triazoles & Dow AgroSciences \\
Propiconazole (41.8) & Tilt 250 & WP & Triazoles & Syngenta \\
Pyraclostrobin (20) & Cabrio & EG & Strobilurins & BASF \\
Pyrimethanil (54.6) & Scala & SC & Anilopyrimidines & Bayer Crop Science \\
Thiophanate-methyl (70) & Topsin-M & WP & Benzimidazoles & United Phosphorus Limited (UPL) \\
Trifloxystrobin (42.6) & Gem 500 & SC & Strobilurins & Bayer Crop Science \\
\hline
\end{tabular}

${ }^{a}$ Numbers in parentheses are percentages of active ingredient.

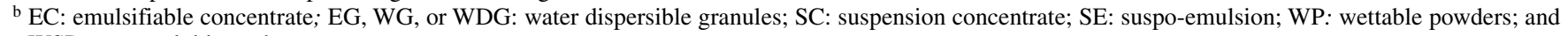
WSP: water soluble packet. 
tions. The main plots were the fungicide treatments and the subplots were fungal pathogens. The experiment was conducted twice. Plates were incubated for 3 days at $25^{\circ} \mathrm{C}$, and at the end of this period $\mathrm{EC}_{50}$ values for mycelial growth of all isolates were determined (13). The four fungicides, azoxystrobin, fludioxonil, metconazole, and pyraclostrobin, with the lowest $\mathrm{EC}_{50}$ and myclobutanil that was among fungicides with higher $\mathrm{EC}_{50}$ (Table 3 ) were selected as treatments for the field experiment. Azoxystrobin and fludioxonil were used in a premix with propiconazole and cyprodinil, respectively, in the field experiment to increase their disease control capacity.

Field experiment. The five fungicide treatments selected from the in vitro experiment were applied at labeled rates. The experimental design was a randomized complete block design with eight blocks. Fungicide, fungal pathogens, and time of inoculation (a day and a week after fungicide treatment) were all factors in the experiment. Each combination of fungicide, fungal pathogen, and time of inoculation occurred one time per block. An additional inoculated check without fungicide treatment for each fungal pathogen also was conducted. The experiment was conducted twice.

The fungicide application and pathogen inoculation were conducted in the following manner: (i) a young avocado branch (with approximately $8 \pm 3 \mathrm{~cm}$ circumference) randomly selected was pruned at its distal end and fungicide was immediately applied to the wound, and (ii) the treated or nontreated (no fungicide application) wounds were inoculated with a mycelial suspension of each fungal pathogen either 1 day or 7 days after fungicide application. Mycelial suspensions were prepared as follows: (i) cultured mycelium was scraped and fragments were ground in sterile distilled water using a blender; (ii) the mixture was filtered through two layers of cheesecloth and then stirred; (iii) a drop of Tween 20 (Sigma-Aldrich) was added; and (iv) the concentration of each fungus was corrected to $3 \times 10^{5}$ mycelial fragments $/ \mathrm{ml}$ using a hemacytometer.

Approximately 6 months after fungicide application and pathogen inoculation, branches were cut off and taken back to the laboratory for disease assessment. Briefly, cut branches were surfacedisinfested with $70 \%$ ethanol and flamed. Subsequently, branches were sectioned longitudinally from the point of inoculation. The internal and external lesion lengths (Fig. 1) and the branch diameter at the noninoculated end were measured. To confirm the cause of the lesion, isolations were conducted using small pieces of necrotic tissue from the edge of each lesion or from area of inoculation, if there was no visible lesion. Necrotic tissue was placed on PDA (Sigma-Aldrich) amended with $0.01 \%$ tetracycline hydrochloride (PDA-tet). Cultures were incubated at room temperature, and as fungal colonies appeared, morphological observations were made to confirm the presence of the fungus used in inoculation.

Statistical analysis. $\mathrm{EC}_{50}$ values from both runs in the in vitro fungicide screening were tested for homogeneity of error variance by analysis of variance (ANOVA) in PROC GLM of SAS (version 9.2; SAS Institute Inc.). As no heterogeneity was detected, pooled data were tested by ANOVA in PROC GLM of SAS. Mean $\mathrm{EC}_{50}$ values among fungicides were compared using a Tukey's honest significant difference (HSD) mean separation test at $\alpha=0.05$. Data from both field trials were analyzed using ANOVA in PROC GLM of SAS, and means for internal and external lesion lengths were compared using Tukey's HSD test at $\alpha=0.05$. Pearson's correlation coefficients were calculated using PROC CORR procedure of SAS to determine the relationship between the internal and external lesion lengths and the branch diameter as well as the relationship between lesion length and $\mathrm{EC}_{50}$ values. Finally, a paired sample $t$ test was conducted to examine whether there were differences between mean internal and external lesion length in both field trials.

\section{Results}

In vitro fungicide screening. There were significant differences $(P<0.05)$ among fungicides, fungal pathogens, and their interaction for $\mathrm{EC}_{50}$ values recorded in the in vitro fungicide screening experiment (Table 3). $\mathrm{EC}_{50}$ values ranged from 0.006 to 2.274 . Pyraclostrobin had consistently lower $\mathrm{EC}_{50}$ when tested with the five fungi; however, its $\mathrm{EC}_{50}$ did not significantly differ $(P>0.05)$ from those of the other four fungicides (azoxystrobin, fludioxonil, metconazole, and propiconazole). Cyprodinil, myclobutanil, Pyrimethanil, and thiophanate-methyl had consistently higher $\mathrm{EC}_{50}$ values, while aluminum tris and fluopyram had $0 \%$ (or no) inhibition when tested against the five fungi (Table 3). Among the fungal pathogens, lowest $\mathrm{EC}_{50}$ values were consistently recorded on $D$. iberica, followed by Phomopsis sp., N. parvum, and N. australe, while highest $\mathrm{EC}_{50}$ values were recorded on $N$. luteum.

Field experiment. A significant difference $(P<0.05)$ was detected among fungicides for both internal and external lesion length; however, there were no significant differences $(P>0.05)$ among fungal pathogens (Table 4). Mean internal and external lesion length also differed significantly $(P<0.05)$ in between both trials with greater disease severity recorded in trial 2 than in trial 1 (Table 5). The three-way interaction: fungicide, fungal pathogen, and trial, also was significant $(P<0.05)$ (Table 4). There was no significant difference between time of inoculation (1 day versus 7 days; $P>0.05)$, nor was there a fungicide by fungal pathogen interaction $(P>0.05)$ (Table 4$)$. As a result, internal and external

Table 3. Mean and standard deviation (in parentheses) of effective concentrations for $50 \%$ reduction of mycelial growth (EC $\mathrm{E}_{50}$ values) of fungal pathogens (Dothiorella iberica, Neofusicoccum australe, N. luteum, N. parvum, and Phomopsis sp. $)^{\mathrm{a}}$ during the in vitro fungicide screening experiment

\begin{tabular}{|c|c|c|c|c|c|c|}
\hline \multirow[b]{2}{*}{ Fungicides } & \multirow[b]{2}{*}{$\begin{array}{l}\text { Concentrations } \\
\text { applied }(\mu \mathrm{g} / \mathrm{ml})\end{array}$} & \multicolumn{5}{|c|}{$\mathrm{EC}_{50}$ for inhibition of mycelial growth $(\mu \mathrm{g} / \mathrm{ml})^{\mathrm{b}}$} \\
\hline & & $\begin{array}{c}\text { Dothiorella } \\
\text { iberica }\end{array}$ & $\begin{array}{c}\text { Neofusicoccum } \\
\text { australe }\end{array}$ & N. luteum & N. parvum & Phomopsis sp. \\
\hline Pyraclostrobin & 100 & $0.006(0.001)$ & $0.006(0.003)$ & $0.006(0.001)$ & $0.008(0.005)$ & $0.005(0.001)$ \\
\hline Azoxystrobin & 100 & $0.006(0.001)$ & $0.008(0.004)$ & $0.011(0.002)$ & $0.005(0.001)$ & $0.008(0.005)$ \\
\hline Metconazole & 100 & $0.010(0.002)$ & $0.008(0.003)$ & $0.014(0.003)$ & $0.008(0.001)$ & $0.010(0.004)$ \\
\hline Fludioxonil & 100 & $0.020(0.006)$ & $0.010(0.002)$ & $0.007(0.001)$ & $0.007(0.001)$ & $0.008(0.002)$ \\
\hline Propiconazole & 100 & $0.012(0.004)$ & $0.013(0.014)$ & $0.028(0.013)$ & $0.009(0.004)$ & $0.019(0.010)$ \\
\hline Trifloxystrobin & 2,000 & $0.078(0.010)$ & $0.220(0.218)$ & $0.119(0.064)$ & $0.121(0.080)$ & $\ldots$ \\
\hline Myclobutanil & 2,000 & $0.193(0.022)$ & $0.236(0.100)$ & $0.400(0.105)$ & $0.199(0.042)$ & $0.124(0.014)$ \\
\hline Thiophanate-methyl & 2,000 & $1.339(0.202)$ & $1.558(0.900)$ & $2.139(0.684)$ & $0.813(0.272)$ & $0.489(0.132)$ \\
\hline Cyprodinil & 100 & $0.548(0.333)$ & $1.333(0.503)$ & $1.337(0.452)$ & $1.473(0.632)$ & $1.808(1.349)$ \\
\hline Pyrimethanil & 3,000 & $\ldots$ & $2.274(0.191)$ & $1.779(0.508)$ & $1.828(1.429)$ & $0.664(0.581)$ \\
\hline Aluminum tris & 2,000 & $\mathrm{NI}^{\mathrm{c}}$ & NI & NI & NI & NI \\
\hline Fluopyram & 3,000 & NI & $\mathrm{NI}$ & NI & $\mathrm{NI}$ & NI \\
\hline $\operatorname{HSD}(\alpha=0.05)^{\mathrm{d}}$ & 0.36 & 1.29 & 0.72 & 1.40 & 1.13 & \\
\hline
\end{tabular}

a Five isolates were tested for each species except for $D$. iberica, which had only three isolates that were tested.

${ }^{\mathrm{b}} \mathrm{EC}_{50}$ values were determined using the spiral gradient dilution method (13). Numbers are mean and standard deviation (in parentheses) of EC ${ }_{50}$ values of all isolates for each species.

c NI: Noninhibition (NI was not included in statistical analysis).

d Tukey's honest significant difference (HSD) $(\alpha=0.05)$. 
lesion length data were averaged across fungal pathogens and time of inoculation for each trial. There was no significant difference among fungicides for the external lesion length in trial 1 (Table 5).

Mean internal lesion lengths ranged from 2.5 to $5.2 \mathrm{~cm}$ and from 4.0 to $10.2 \mathrm{~cm}$ in trial 1 and trial 2, respectively (Table 5). Pruned branches sprayed with azoxystrobin + propiconazole had the low-

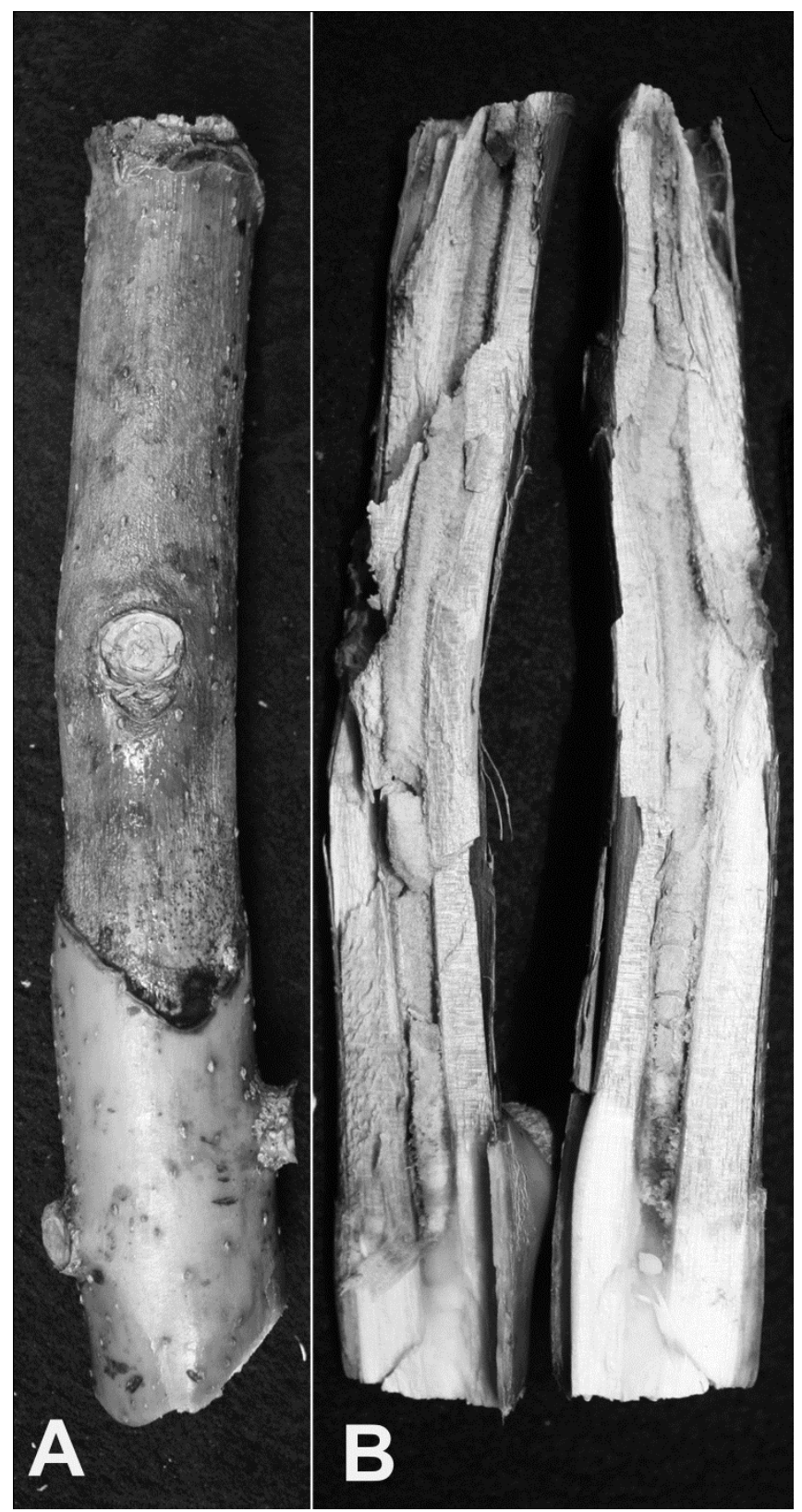

Fig. 1. External $(\mathbf{A})$ and internal $(B)$ lesions on pruned avocado branch inoculated with $3 \times 10^{5}$ mycelial fragments $/ \mathrm{ml}$ of Neofusicoccum parvum. est mean internal lesion length across both trials, 2.5 and $4.0 \mathrm{~cm}$ in trial 1 and trial 2, respectively. These numbers correspond to $52 \%$ (trial 1) and 61\% (trial 2) inhibition for internal lesion. Mean external lesion lengths ranged from 2.6 to $4.1 \mathrm{~cm}$ and from 3.1 to 8.9 $\mathrm{cm}$ in trial 1 and trial 2 , respectively (Table 5). Similarly to internal lesion length, azoxystrobin + propiconazole had the lowest mean external lesion length across both trials, 2.6 and $3.0 \mathrm{~cm}$ in trial 1 and trial 2, respectively. The level of inhibition recorded on azoxystrobin + propiconazole for both internal and external lesion length was not significantly different $(P>0.05)$ from that of metconazole. Myclobutanil, which was among fungicides that had higher $\mathrm{EC}_{50}$ values in the in vitro fungicide screening, had the highest mean numbers of internal and external lesion lengths in the field trial (Table 5).

Although there was a significant difference $(P<0.05)$ between internal and external mean lesion length in the field experiments, Pearson's correlation coefficient indicated a strong correlation between the two variables $(r=0.91, n=956, P<0.0001)$. A low but significant negative correlation was also detected between internal $(r=-0.12, P=0.0002)$ and external $(r=-0.12, P=0.0001)$ lesion length and branch diameter. Moreover, there was a significant relationship between internal $(r=0.51, P<0.05)$ and external $\left(r=0.55, P=0.03\right.$ ) lesion length in the field experiment and $\mathrm{EC}_{50}$ value data from in vitro fungicide screening.

\section{Discussion}

The fungi that cause branch canker of avocado infect through wounds mostly caused by pruning activities. The management of pathogens involved in branch canker relies primarily on good cultural practices such as pruning out dead limbs and twigs, removal of pruning waste from avocado fields, and minimizing stresses (36). However, other control methods such as using fungicides are very important, as cultural practices are most often not effective.

Although there have not been reports on fungicide application for controlling fungi in the family Botryosphaeriaceae responsible for avocado branch canker, fungicides have been used on avocados to control trunk canker infections caused by other pathogens. For instance, fungicide treatments with Fosetyl-Al [Aluminum tris (oethyl phosphonate)], Fosetyl Al + Tree Seal, metalaxyl, Bordeaux mixture, and Tree Paint have been used for curing as well as protecting avocado against trunk canker disease caused by Phytophthora citricola (6). Fosetyl-Al was considered to be highly effective in controlling trunk canker disease because of its capacity to be translocated in both xylem and phloem $(4,7)$.

Based on our in vitro fungicide screening results, five fungicide treatments were the most effective, because of their low $\mathrm{EC}_{50}$ values, at inhibiting mycelial growth of isolates of the five fungal pathogens D. iberica, $N$. australe, N. luteum, N. parvum, and Phomopsis sp. They included azoxystrobin, fludioxonil, metconazole, propiconazole, and pyraclostrobin. Similarly, treatments comprising fludioxonil inhibited mycelial growth of Botryosphaeria dothidea, Diplodia seriata, Lasiodiplodia theobromae, Neofusicoccum parvum, $N$. luteum, and $N$. australe $(1,22,33,35)$. In another report, when 14 fungicides in different chemical families were tested in vitro to evaluate their effectiveness at inhibiting mycelial growth of Botryosphaeria corticola (cork oak canker), the most

Table 4. Variation among fungicides, fungal pathogens, between trials and time of inoculation, and interactions for internal and external lesion lengths during the field experiment

\begin{tabular}{|c|c|c|c|c|c|c|c|}
\hline \multirow[b]{3}{*}{ Source of variation } & \multirow[b]{3}{*}{ df } & \multicolumn{6}{|c|}{ Lesion length (cm) } \\
\hline & & \multicolumn{3}{|c|}{ Internal } & \multicolumn{3}{|c|}{ External } \\
\hline & & MS & $F$ value & $P>F$ & MS & $F$ value & $P>F$ \\
\hline Fungicide & 5 & 362.2 & 7.5 & $<0.0001$ & 238.4 & 4.6 & 0.0004 \\
\hline Pathogen & 4 & 53.2 & 1.1 & 0.3545 & 29.4 & 0.6 & 0.6884 \\
\hline Trial & 1 & $2,492.9$ & 51.6 & $<0.0001$ & $1,937.8$ & 37.2 & $<0.0001$ \\
\hline Time of inoculation & 1 & 36.1 & 0.8 & 0.3877 & 9.8 & 0.2 & 0.6645 \\
\hline Fungicide $\times$ pathogen & 20 & 60.9 & 1.3 & 0.1974 & 56.2 & 1.1 & 0.3647 \\
\hline Fungicide $\times$ pathogen $\times$ trial & 29 & 84.6 & 1.8 & 0.0087 & 90.9 & 1.8 & 0.009 \\
\hline
\end{tabular}


effective fungicides were benomyl, carbendazim, cyprodinil + fludioxonil, thiabendazol, and thiophanate-methyl (21). Furthermore, carbendazim and thiophanate-methyl were the most effective in suppressing mycelium growth of $B$. dothidea in vitro (20); however, the effectiveness of thiophanate-methyl was in contrast with the results in our study, as it was found to be ineffective at inhibiting mycelial growth of the five fungal pathogens used. Similarly, Aluminum tris (-0-ethyl phosphonate), which was considered to be highly effective in controlling trunk canker disease $(4,7)$, was ineffective in our in vitro fungicide screening. Fludioxonil, myclobutanil, and pyraclostrobin were fungicides with low $\mathrm{EC}_{50}$ values in fungicide evaluation for the management of Botryosphaeria canker of grapevines (33). In our in vitro fungicide screening, myclobutanil was found to be ineffective, as it was among fungicides that had high $\mathrm{EC}_{50}$ values at inhibiting mycelial growth of isolates of the five fungal pathogens.

In our field trial, azoxystrobin + propiconazole, and metconazole had the greatest inhibition of internal and external growths of $D$. iberica, N. australe, N. luteum, N. parvum, and Phomopsis sp. Although there have been some reports on the use of azoxystrobin + propiconazole in the control of some fungal diseases $(25,29)$, this mixture has not been used to manage fungi in the family Botryosphaeriaceae causing branch canker of avocado. Applied alone, azoxystrobin reduced the disease severity of constriction canker of peach caused by Phomopsis amygdale by $41 \%$ (19). Similarly, azoxystrobin caused a significant decrease of stem canker (Leptosphaeria maculans and L. biglobosa) in winter oilseed rape crops (34). When applied alone, propiconazole inhibited the infection of Phomopsis amygdale (constriction canker of peach) by $44 \%$ (19). Metconazole, which had similar results to azoxystrobin + propiconazole in our field trial, was reported to be efficacious in oilseed rape protection against stem canker (Leptosphaeria maculans and L. biglobosa) (18) and other diseases $(5,32)$.

The fungicides resulting in the greatest reduction in disease (azoxystrobin + propiconazole and metconazole) in our field trials had percent inhibition that ranged from 35 to $61 \%$. These fungicides were applied for preventive protection a day or a week before the fungal inoculations; to maximize their control activity these fungicides may be applied at regular intervals as has been reported in the control of other diseases $(29,30)$. Fungicides applied only once may lose their control ability mostly due to their dilution in the plant or tree tissues over time and to the deposition of new spores that can reinforce the infection.

There were no significant differences in inoculating pruned branches a day or a week after fungicide application in our field trials, indicating that the 1-week interval might have been too short to observe differences in fungicide residual activity. Although significant differences were observed between means of internal and external lesion lengths in the field trials, the strong correlation between them indicates only one measurement would be necessary, simplifying disease rating. The significant relationship between lesion length in the field trials and $\mathrm{EC}_{50}$ values in the in vitro experiment means that fungicides that could inhibit the mycelial growth in vitro were also effective in limiting fungal infection in the field.

To the best of our knowledge, this is the first study that deals with the control of Botryosphaeriaceae and Phomopsis spp. that cause the branch canker of avocado in California. Regular prophylactic use of fungicides, especially if combined with sanitation pruning, will result in an appreciable decrease in disease severity. Additional studies need to be carried out to optimize fungicide application. In particular, epidemiological studies which would improve the timing and frequency of fungicide application would be useful. Furthermore, cultural practices such as pruning and canker removal and fungicide applications should be investigated more fully as an integrated form of disease management.

\section{Acknowledgments}

We thank the California Avocado Commission and its members for funding and supporting this research; and H. Förster and J. E. Adaskaveg for their technical assistance on the use of fungicides.

\section{Literature Cited}

1. Bester, W., Crous, P. W., and Fourie, P. H. 2007. Evaluation of fungicides as potential grapevine pruning wound protectants against Botryosphaeria species. Australas. Plant Pathol. 36:73-77.

2. Brooks, F. E., and Ferrin, D. M. 1994. Branch dieback of southern California chaparral vegetation caused by Botryosphaeria dothidea. Phytopathology 84:78-83.

3. California Avocado Commission. 2010-2011. Unprecedented performance: Progress towards sustainable value. Calif. Avocado Comm. Annu. Rep. 12, Mauchly, Irvine, CA.

4. Cohen, Y., and Coffey, M. D. 1986. Systemic fungicides and the control of Oomycetes. Annu. Rev. Phytopathol. 24:311-338.

5. Dardis, J. V., and Walsh, E. J. 2000. Studies on the effectiveness of metconazole in controlling Fusarium head blight caused by Fusarium culmorum in spring wheat (Triticum aestivum L). Cereal Res. Comm. 28:443-448.

6. El-Hamalawi, Z. A., and Menge, J. A. 1994. Effect of wound age and fungicide treatment of wounds on susceptibility of avocado stems to infection by Phytophthora citricola. Plant Dis. 78:700-704.

7. El-Hamalawi, Z. A., Menge, J. A., and Guillemet, F. B. 1995. Infection court and factors affecting expansion of stem canker of avocado caused by Phytophthora citricola. Plant Dis. 79:384-388.

8. English, H., Davis, J. R., and DeVay, J. E. 1966. Dothiorella canker, a new disease of almond trees in California (Abstr.) Phytopathology 56:146.

9. Eskalen, A., Faber, B., and Bianchi, M. 2012. Spore trapping and pathogenicity of fungi in the Botryosphaeriaceae and Diaporthaceae associated with avocado branch canker in California. Plant Dis. 97:329-332.

10. Eskalen, A., Feliciano, A. J., and Gubler, W. A. 2007. Susceptibility of grapevine pruning wounds and symptom development in response to infection by Phaeoacremonium aleophilum and Phaeomoniella chlamydospora. Plant Dis. 91:1100-1104.

11. Evans, E. A., and Nalampang, S. 2009. An analysis of the U.S. demand for avocado (Persea americana Mill.). Acta Hortic. 831:247-254.

Table 5. Internal and external mean lesion length recorded on avocado branches treated with different fungicides and inoculated with fungal pathogens (Dothiorella iberica, Neofusicoccum australe, N. luteum, N. parvum, and Phomopsis sp.) $)^{\text {a }}$ during the field experiment

\begin{tabular}{|c|c|c|c|c|c|}
\hline \multirow[b]{3}{*}{ Fungicide $^{c}$} & \multirow{3}{*}{$\begin{array}{l}\text { Field rate } \\
\text { (kg a.i./ha) }\end{array}$} & \multicolumn{4}{|c|}{ Lesion length $(\mathrm{cm})^{b}$} \\
\hline & & \multicolumn{2}{|c|}{ Trial 1} & \multicolumn{2}{|c|}{ Trial 2} \\
\hline & & Internal & External & Internal & External \\
\hline Azoxystrobin + propiconazole & $0.18+0.16$ & 2.5 & 2.6 & 4.0 & 3.1 \\
\hline Metconazole & 0.14 & 2.9 & 2.7 & 4.9 & 4.3 \\
\hline Pyraclostrobin & 0.22 & 3.3 & 3.5 & 6.7 & 6.2 \\
\hline Fludioxonil + cyprodinil & $0.24+0.34$ & 4.0 & 3.4 & 6.8 & 6.5 \\
\hline Myclobutanil & 0.17 & 3.7 & 3.6 & 8.4 & 7.7 \\
\hline Water control & $\ldots$ & 5.2 & 4.1 & 10.2 & 8.9 \\
\hline $\operatorname{HSD}(\alpha=0.05)^{\mathrm{d}}$ & & 2.5 & ns & 2.6 & 3.0 \\
\hline
\end{tabular}

${ }^{a}$ Isolates UCR452 (D. iberica), UCR509 (N. australe), UCR516 (N. luteum), UCR295 (N. parvum), and UCR556 (Phomopsis sp.) were tested in the field experiment.

b Internal and external mean lesion lengths were averaged by fungal pathogens and time of inoculation, as there were no significant differences among fungal pathogens and between times of inoculation.

c Azoxystrobin and fludioxonil were used in a premix with propiconazole and cyprodinil, respectively. Quilt Xcel and Switch 62.5 (Syngenta Crop Protection, Greensboro, NC) were used for azoxystrobin + propiconazole and fludioxonil + cyprodinil, respectively.

d Tukey's honest significant difference (HSD) $(\alpha=0.05)$. 
12. FAO. 2011. Food and Agricultural Organization. http://faostat.fao.org

13. Förster, H., Kanetis, L., and Adaskaveg, J. E. 2004. Spiral gradient dilution, a rapid method for determining growth responses and 50\% effective concentration values in fungus-fungicide interactions. Phytopathology 94:163170 .

14. Goodall, G. E., Embleton, T. W., and Platt, R. G. 1981. Avocado fertilization. University of California Division of Agricultural Science, Oakland, CA, USA. Leaflet 2024.

15. Halma, F. F., and Zentmyer, G. A. 1953. Relative susceptibility of Guatemalan and Mexican avocado varieties to Dothiorella canker. Calif. Avocado Soc. Yearb. 38:156-158.

16. Horne, W. T. 1932. Pests and diseases-latest developments in avocado disease control. Calif. Avocado Assoc. Yearb. 17:33-37.

17. Johnson, G. I. 1994. Dothiorella stem canker and fruit rot. Pages 81-83 in: Compendium of Tropical Fruit Diseases. R. C. Ploetz, G. A. Zentmyer, W. T. Nishijima, K. G. Rohrbach, and H. D. Ohr, eds. American Phytopathological Society, St Paul, MN.

18. Karolewski, Z., Wachowiak, M., Ratajkiewicz, H., and Kierzek, R. 2009. Effect of adjuvants and spray application factors on metconazole activity against Leptosphaeria biglobosa and L. maculans during late spring treatments in winter oilseed rape. J. Plant Prot. Res. 49:113-117.

19. Lalancette, N., and Robison, D. M. 2002. Effect of fungicides, application timing, and canker removal on incidence and severity of constriction canker of peach. Plant Dis. 86:721-728.

20. Li, H. Y., Cao, R. B., and Mu, Y. T. 1995. In vitro inhibition of Botryosphaeria dothidea and Lasiodiplodia theobromae, and chemical control of gummosis disease of Japanese apricot and peach trees in Zhejiang Province, China. Crop Prot. 14:187-191.

21. Luque, J., Pera, J., and Parladé, J. 2008. Evaluation of fungicides for the control of Botryosphaeria corticola on cork oak in Catalonia (NE Spain). For. Pathol. 38:147-155.

22. Ma, Z., Morgan, D. P., Felts, D., and Michailides, T. J. 2002. Sensitivity of Botryosphaeria dothidea from California pistachio to tebuconazole. Crop Prot. 21:829-835.

23. McDonald, V., and Eskalen, A. 2011. Botryosphaeriaceae species associated with avocado branch cankers in California. Plant Dis. 95:1465-1473.

24. McDonald, V., Lynch, S., and Eskalen, A. 2009. First report of Neofusicoccum australe, N. luteum, and N. parvum associated with avocado branch canker in California. Plant Dis. 93:967.

25. McKay, A. H., Förster, H., and Adaskaveg, J. E. 2012. Efficacy and applica- tion strategies for propiconazole as a new postharvest fungicide for managing sour rot and green mold of citrus fruit. Plant Dis. 96:235-242.

26. Menge, J., and Ploetz, R. C. 2003. Diseases of avocado. Pages 35-71 in: Diseases of Tropical Fruit Crops. R. C. Ploetz, ed. CABI Publishing, Wallingford, UK

27. Michailides, T. J. 1991. Pathogenicity, distribution, sources of inoculum, and infection courts of Botryosphaeria dothidea on pistachio. Phytopathology 81:566-573.

28. Michailides, T. J., and Morgan, D. P. 2004. Panicle and shoot blight of pistachio: A major threat to the California pistachio industry. APSnet Feature Story. Published online.

29. Miles, M. R., Levy, C., Morel, W., Mueller, T., Steinlage, T., van Rij, N., Frederick, R. D., and Hartman, G. L. 2007. International fungicide efficacy trials for the management of soybean rust. Plant Dis. 91:1450-1458.

30. Mmbaga, M. T., and Sauvé, R. J. 2004. Management of powdery mildew in flowering dogwood in the field with biorational and conventional fungicides. Can. J. Plant Sci. 84:837-844.

31. Morgan-Jones, G., and White, J. F. 1987: Notes on Coelomycetes. II. Concerning the Fusicoccum anamorph of Botryosphaeria ribis. Mycotaxon 30:117-125.

32. Pirgozliev, S. R., Ray, R. V., Edwards, S. G., Hare, M. C., and Jenkinson, P. 2008. Effect of timing of fungicide application on the development of Fusarium head blight and the accumulation of deoxynivalenol (DON) in winter wheat grain. Cereal Res. Comm. 36:289-299.

33. Pitt, W. M., Sosnowski, M. R., Huang, R., Qiu, Y., Steel, C. C., and Savocchia, S. 2012. Evaluation of fungicides for the management of Botryosphaeria canker of grapevines. Plant Dis. 96:1303-1308.

34. Ratajkiewicz, H., Kierzek, R., Karolewski, Z., and Wachowiak, M. 2009. The effect of adjuvants, spray volume and nozzle type on azoxystrobin efficacy against Leptosphaeria maculans and L. biglobosa on winter oilseed rape. J. Plant Prot. Res. 49:440-445.

35. Savocchia, S., Laurent, E. N., Stodart, B. J., and Steel, C. C. 2004. Botryosphaeria canker and sensitivity to fungicides in vitro. 43rd Southern African Society for Plant Pathology Congr., Hartenbos, South Africa.

36. University of California Statewide Integrated Pest Management Program. 2008. Integrated Pest Management for Avocados. University of California (System). Oakland, CA.

37. Úrbez-Torres, J. R., Leavitt, G. M., Voegel, T. M., and Gubler, W. D. 2006 Identification and distribution of Botryosphaeria spp. associated with grapevine cankers in California. Plant Dis. 90:1490-1503. 